\title{
Explaining the influence of time budgetpressure on audit quality in Sweden
}

Pernilla Broberg, Torbjörn Tagesson, Daniela Argento, Niclas Gyllengahm and Ola Mårtensson

The self-archived postprint version of this journal article is available at Linköping University Institutional Repository (DiVA):

http:// urn.kb.se/ resolve?urn=urn:nbn:se:liu:diva-142528

N.B.: When citing this work, cite the original publication.

The original publication is available at www.springerlink.com:

Broberg, P., Tagesson, T., Argento, D., Gyllengahm, N., Mårtensson, O., (2017), Explaining the influence of time budgetpressure on audit quality in Sweden, J ournal of Management and Governance, 21(2), 331-350. https://doi.org/ 10.1007/s10997016-9346-4

Original publication available at:

https:// doi.org/ 10.1007/ s10997-016-9346-4

Copyright: Springer Verlag (Germany)

http:// www.springerlink.com/?MUD=MP 


\title{
Explaining the Influence of Time Budget Pressure on Audit Quality in Sweden
}

\author{
Pernilla Broberg \\ Kristianstad University \& Linköping University, Sweden \\ Torbjörn Tagesson \\ Linköping University, Sweden \\ Daniela Argento \\ Kristianstad University, Sweden \\ Niklas Gyllengahm \\ MSc from Kristianstad University, currently working at Grant Thornton, Malmö, Sweden \\ Ola Mårtensson \\ MSc from Kristianstad University, Sweden
}

\begin{abstract}
This paper is aimed at explaining how time budget pressure influences audit quality in the Swedish context. A hypothesis is deduced and tested through a survey sent to Swedish auditors. The Swedish context provides a special setting since audit firms and auditors have been facing new pressures due, for example, to the removal of statutory audits for a majority of the companies in Sweden. The findings show that time budget pressure lowers the quality of audits performed by Swedish auditors, but it is not the only explanation. Audit quality is also related to other factors such as gender, position, experience, number of clients, local office size and audit firm. Thus, the model is useful for explaining the factors influencing audit quality and could be used and expanded in future studies. The study also has practical implications showing that when trading-off between audit efforts and available resources and setting time budgets for each audit assignment, audit firms should also consider the personal characteristics of the auditors.
\end{abstract}

Keywords: Time budget pressure, Audit quality, Auditors, Audit firm, Sweden 


\section{Introduction}

Research in the auditing field raises a general concern about the quality of audits (Liyanarachchi \& McNamara, 2007; Pierce \& Sweeney, 2004; Otley \& Pierce, 1996a). The quality of an audit (AQ) is a sensitive issue to both practitioners and researchers because of the difficulties in measuring it. Herrbach (2001) explains that AQ is characterized by a strong equivocation, which makes it difficult to gauge, unlike other economic activities where quality can be reported in a more accurate way. Liyanarachchi and McNamara (2007), Pierce and Sweeney (2004), and Otley and Pierce (1996a) agree that the quality of the audit can be guaranteed only by the reputation of and trust in the auditors. These authors also say that the importance of auditors' reputation and trustworthiness has increased lately due to a number of major auditing scandals. These scandals led to increased pressure on the audit firms to produce high AQ (Liyanarachchi \& McNamara, 2007; Pierce \& Sweeney, 2004; Otley \& Pierce, 1996a). In addition, as highlighted by Sikka (2009), the deepening financial crisis has posed questions about the role and value of external audits because many financial institutions collapsed or had to be bailed out shortly after receiving unqualified audit opinions. Sikka argues that such events fuel the suspicion that auditors lack the claimed expertise to render an independent and objective account of corporate affairs. Thus, in order to justify its function, role and value, the audit profession is under pressure to produce high $\mathrm{AQ}$, and this prevailing situation forms the background of this study.

Institutional pressures in terms of different isomorphic forces have been shown to affect organizational behaviour (Oliver, 1991). Usually one talks about adaptation or changes of strategy and structure of the firms in relationship to the institutional pressures, which consequently leads to changes in how organizations position themselves and act on the market. For the auditing profession, institutional pressures emerge, firstly, due to the more or less constant changes in the audit industry and its gradual deregulation and secondly, due to the scandals the audit firms have been part of, and which in turn have generated stakeholders' suspicions and regulation affecting the profession. Deregulation of the industry has led to decreasing customer base for audit services and increasing customer base for non-audit services. These developments have in turn led to changes associated with strategy and structure that now have to be adjusted to fit the demands imposed by the external environments. Stakeholder pressure affects how audit firms deal with their quality stances as well as how ethical aspects are being dealt with and communicated. Apart from changes in strategy and structure which often lead to change in organizational behaviour, audit firms now also are 
forced to become very aware of corporate social responsibility (CSR) strategies and actions. More specifically, audit firms, due to the institutional pressure and changes, have become much more commercially oriented, which means that they are more aware of the market. In their effort to meet market expectations on AQ and price (Bowrin and King, 2010) they are trying be more market-oriented, more customer-oriented as well as more business process-oriented (Broberg et al., 2014). Audit firms adopt regular business stances (e.g. Gundry \& Liyanarachchi, 2007) via cost-cutting programs, efficiency-boosting makeovers while at the same time maintaining the CSR image. This creates tensions on the organizational level given that being commercial and maintaining professional ethics might not always follow the same logic. Such tensions on the organizational level affect how individual auditors are behaving/expected to behave. Consequently, cost-cutting while retaining or even increasing AQ and maintaining the professional ethical stance has been associated with pressure, i.e. time budget pressure (TBP), experienced by auditors. In this paper we focus on how such TBP influences auditor performance in terms of AQ.

Several studies have concluded that time budgeting exists in the auditing industry, and auditors constantly have to trade off the time dedicated to auditing and its quality, against the cost of performing it (Ettredge et al., 2008; Liyanarachchi \& McNamara, 2007; Pierce \& Sweeney, 2004; Otley \& Pierce, 1996a; McDaniel, 1990). Sweeney and Pierce (2004) claim that if audit firms budget more time for auditing, the quality of the audit increases, but it also leads to higher costs for the audit firms and, ultimately, to higher fees for clients. Following such reasoning, Gundry and Liyanarachchi (2007) state that AQ is compromised by higher than optimal TBP. That is, auditors feel pressured because they have to fulfil their duties within the time budget that is set for an assignment (Pierce \& Sweeney, 2004).

In recent years, audit services have become more exposed to competition, which in turn has led to a sharp fall in audit fees (Paino et al., 2010; Houston, 1999). Hence, TBP is probably more than ever before an essential part of audit practice. This is revealed not only, for example, in the planning of an audit but also in everyday auditor activities where, for instance, time reporting as well as the ability to balance between different tasks and to prioritize are central parts of auditor work (Broberg, 2013; Broberg et al., 2013). Gaertner and Ruhe (1981) argue that TBP causes a negative stress that influences auditors' efficiency, productivity and personal health. In terms of well-being, Umans et al. (2016) find a relatively high level of job satisfaction among auditors. Nevertheless, various studies show that, due to TBP, auditors might not be able to perform the work that is expected from them (Gundry \& Liyanarachchi, 2007), which leads 
to lower AQ because of less effective evidence gathering (Coram, Ng, \& Woodliff, 2004; Pierce \& Sweeney, 2004; Otley \& Pierce, 1996a; Kelley \& Margheim, 1990; McNair, 1987).

The relationship between TBP and AQ has been discussed in the literature (Bowrin \& King, 2010; Liyanarachchi \& McNamara, 2007; Coram et al., 2004; Coram, Ng, \& Woodliff, 2003; Otley \& Pierce, 1996a). However, the studies mentioned have been performed with small samples and have focused on Anglo-Saxon countries. Among the few exceptions are the studies conducted by Ittonen and Peni (2012) in Sweden, Finland and Denmark and Ittonen et al. (2013) in Sweden and Finland, who analysed the relationship between gender and AQ in the Scandinavian context.

This paper is aimed at explaining how time budget pressure influences audit quality in the Swedish context. In Sweden, requirements for the audit of limited companies were introduced in the 1895 Companies Act (Öhman and Wallerstedt, 2012). In order to prevent financial fraud in small limited companies, the auditor's role was strengthened and regulated when requirements for formal training and certification of auditors were introduced in the 1983 Companies Act (ibid.). According to that legislation, all limited companies had to have at least one authorized or approved public auditor (SFS, 1982:739). Consequently, the legislation at the time meant that the demand for audit services was assured. However, in November 2010 the statutory audits were abolished for smaller limited companies, meaning that the audit became optional and voluntary for 250,000 of the country's approximately 350,000 limited companies. Hence, auditors in Sweden are now experiencing growing competition and an increased responsibility to obtain and keep clients (Broberg, 2013).

Broberg (2013) studied Swedish auditors and found a strong firm influence on audit practice and that the emergent need of being 'client-friendly' means that auditors' everyday practices and behaviours are influenced by a strong client orientation rather than merely a purely professional orientation. In addition, Swedish auditing has been affected by the ongoing globalization and harmonization as, among other things, Swedish auditing standards have been replaced by International Standards on Auditing (ISA).

Changes and developments in the audit profession, at international and national as well as industry and firm level, are often made in the name of audit quality. At the same time, such changes and developments might not always follow the same logic; for instance, there is a contradiction between TBP and AQ. The public, regulators, professional organizations, stakeholders, clients and the employer (the audit firm) exert continuous pressure on auditors 
and their performance. In other words, there are expectations from society, audit firms and clients that individual auditors ensure audit quality, but in real practice - for different reasons, e.g. TBP - these auditors can be decoupled and engage in audit quality-reducing practices. Thus, by studying the Swedish setting we intend to capture much of these pressures and contradictions and to contribute to the existing literature by providing additional insights into the influence of TBP on AQ.

The remainder of this paper is structured as follows. Section 2 reviews the theoretical literature and develops the hypothesis underlying this study. Section 3 describes the data collection and empirical method adopted to test the hypothesis. Section 4 is dedicated to the analyses. Section 5 comprises a discussion of the main results and findings. The paper ends with concluding remarks in Section 6.

\section{Theory}

Audit quality is an important concept within the auditing field. To be able to carry out high quality audits, regulators (EC, 2010) and the audit profession (IAASB, 2010; IFAC, 2011; ICAEW, 2002) as well as researchers (Broberg, 2013; Dillard \& Bricker, 1992; Warren, 1984) emphasize the importance of auditors maintaining professional scepticism and making professional judgments. Maintaining professional scepticism is important to reduce risks of overlooking unusual circumstances, overgeneralizing when drawing conclusions from audit observations, and using inappropriate assumptions in determining the nature, timing and extent of the audit procedures and evaluating the results (ISA 200, A19). Making professional judgment is necessary when it comes to, for example, decisions about materiality and risk, sufficient and appropriate audit evidence as well as the nature, timing and extent of audit procedures (ISA 200, A23). Fisher (1996) argues that one of the most important judgments for auditors to make is about what constitutes a quality audit. Such judgment is about sufficiency; for example, when is sufficient evidence obtained?

It is often stated that high AQ is difficult to define and measure (Colbert \& Murray, 1999). Sometimes AQ is instead discussed in terms of reduced AQ, i.e. low AQ, and more specifically what behaviour entails reduced AQ. Coram et al. (2008), Kelley and Margheim (1990), and McNair (1987) define reduced AQ as actions that intentionally and inappropriately reduce the gathering of audit evidence. The common denominator in the definitions of and discussions on 
AQ seems to be that it is seen as the desired outcome of the auditing process and that auditor behaviour and actions are central inputs in such a process.

Auditor behaviour as well as conduct and appearance are closely linked to 'professionalism' within auditing (Cooper \& Robson, 2006; Anderson-Gough et al., 2000, 2001, 2002; Alvesson, 1994; Grey, 1998). The importance of conduct and appearance has been emphasized by, for example, Dirsmith and Covaleski (1985), Power (1991), Fogarty (1992), Pentland (1993), Grey (1998), Dirsmith et al. (1997), Anderson-Gough et al. (2000; 2001; 2002) and Kosmala (2005). It has to do with adhering to dress codes and submitting to long working hours (cf. Pentland, 1993; Covaleski et al., 1998; Grey, 1998; Anderson-Gough et al., 2000, 2001, 2002). Also, the sharing of common values, a common language and a feeling of identity are important characteristics within a profession (Anderson-Gough et al., 2000; Brante, 1988). AndersonGough et al. (2000) suggest that auditor behaviour, conduct and appearance are learnt through formal and informal processes (i.e. socialization) from which individual auditors become functioning members of the collective. Socialization could also be argued to be a type of internal control. Grey (1998) claims that behavioural norms are produced and reproduced within audit firms and therefore audit firm culture is to some extent determining what 'being a professional auditor' is about. Thus, just as following the firm's auditing procedures, socialization is a crucial part in the process of becoming an auditor (Anderson-Gough et al., 2001). It has even been argued that professionalism within auditing has more to do with auditor behaviour, conduct and appearance than with expert knowledge, which is seen more as a type of requirement (Anderson-Gough et al., 2000; Grey, 1998).

Anderson-Gough et al. (2000) claim that audit firm clients are an important part of the socialization process as the client concept is used, for example, to mediate explanations of events and legitimize certain practices. As audit firms also include services such as tax advice and management consulting, they are more often referred to as 'professional service firms'; to serve the client, to be 'client-friendly' and to present a professional image to clients are central matters. Heischmidt et al. (2002) claim that the practices and attitudes among auditors and audit firms have changed due to increased competition. Increased competition within the auditing sector has also been claimed by Paino et al. (2010) and Houston (1999); it has been argued that being 'cost competitive, commercially aware and biased in favour of the paying customer' is necessary to be successful (Hanlon, 1996: 345). Also, a tight time budget has been claimed to create cost control that maximizes audit firms' fixed profit (Ettredge et al., 2008). Based on fieldwork within the Big 4 audit firms, Broberg (2013) concludes that cost competitiveness and 
commercial awareness are present in everyday auditor work and manifested as auditors are defining AQ not only in terms of, for example, sufficiency and applying scepticism but also in terms of customer (client) satisfaction. This ‘service approach’ has also been emphasized in several studies focusing on marketing aspects within auditing firms (cf. Broberg et al., 2013; Clow et al., 2009; Ellingson et al., 2002; Tang et al., 2002; Heischimdt et al., 2002) and on effects of auditors providing non-audit services (Kinney et al., 2004; Larker \& Richardson, 2004). From being seen among auditors as unethical practice (Clow et al., 2009; Heischmidt et al., 2002), marketing is now recognized as important and as something auditors are engaged in during their daily work (Broberg et al., 2013).

There are a large number and wide range of studies focusing on AQ. However, it is often argued that $\mathrm{AQ}$ is a difficult concept to define and it has been claimed that it is difficult to measure (Colbert \& Murray, 1999; Francis, 2011; Knechel et al., 2013). However, it seems uncontroversial to state that AQ has to do with auditor effort (e.g. Power, 2003).

Auditor effort might instead be discussed in terms of TBP. TBP could be seen as a consequence of audit firms and auditors striving for lower audit fees (Ettredge et al., 2008) and trying to serve the client (as discussed above). Such pressures could lead to auditors not being able to carry out the work that is expected from them (Gundry \& Liyanarachchi, 2007; Alderman \& Deitrick, 1982) as auditors, for example, might accept more risk in their audit (Ettredge et al., 2008). For instance, López and Peters (2010) found a positive relationship between clients’ abnormal accruals and the auditors' workload. Hence, TBP could entail quality-threatening/reducing behaviour (Bowrin \& King, 2010; Ettredge et al., 2008; Gundry \& Liyanarachchi, 2007; Pierce \& Sweeney, 2003, 2006; Sweeney \& Pierce, 2006; Coram et al., 2003; AndersonGough et al., 2001; Malone \& Roberts, 1996; Otley \& Pierce, 1996a, 1996b; Kelley \& Margheim, 1990; Alderman \& Deitrick, 1982). Premature sign-off, i.e. auditors signing off audit steps before the assignment is fully completed, is one example of such behaviour and of insufficient effort (Liyanarachchi \& McNamara, 2007; Sweeney \& Pierce, 2006; Shapeero et al., 2003; Malone \& Roberts, 1996; Otley \& Pierce, 1996a, 1996b; Raghunathan, 1991; Margheim \& Pany, 1986; Hyatt \& Taylor, 2013). Auditors negotiating fees and deliberately underestimating or understating them (so-called low-balling) has also been discussed as reducing AQ. Otley and Pierce (1996a, 1996b), as well as Sweeney and Pierce (2006), argue that such dysfunctional behaviour appears when auditors use their own spare time to complete an assignment (that is, underreporting of time). If auditors report less time than the time actually spent on an assignment, then the time budget could be tightened in the future by creating even 
more pressures which, in turn, could lead to audit quality-reducing behaviours. Moreover, disputes between auditors and their clients (Palmrose, 1986) and acceptance of doubtful and/or weak client explanations (Coram et al., 2004; Malone \& Roberts, 1996; Otley \& Pierce, 1996a, 1996b; Kelley \& Margheim, 1990) have been claimed to signal reduced AQ.

The foregoing discussion indicates that behaviour and actions that reduce auditor effort and that set professional scepticism and professional judgment aside are causing reduced AQ, i.e. audits with lower quality. Auditors perceiving pressures from the time budget set for their assignments can sign off audit steps before they are completed, accept doubtful and/or weak explanations from clients, and/or underreport time spent on engagements. This means that they are neither maintaining scepticism nor making professional judgments and therefore carrying out audits with reduced quality. This paper argues that under TBP auditors are more inclined to engage in such quality-reducing behaviour. These arguments lead to the following hypothesis:

Hypothesis: Time budget pressure is negatively correlated with audit quality.

\section{Method}

\subsection{Selection of data}

The empirical data in this study are based on a survey sent to all certified (authorized and approved public auditors) in Sweden during spring 2012 (cf. Gyllengahm \& Mårtensson, 2012). In total, 854 auditors of the total population of 3596 certified auditors responded to our survey. However, 108 of the answers were incomplete, which means that 746 responses were used in the analysis. Thus, the empirical data are based on responses from $20.7 \%$ of the certified auditors in Sweden. In the non-respondent analysis we used a Pearson Chi-Square test in order to compare the respondents with non-respondents regarding gender and formal competence. The test did not indicate any bias regarding gender $(\mathrm{p}=0.972)$. Regarding position, there was a small bias ( $\mathrm{p}=0.046)$ with 24 approved public auditors more than the expected count and thus 24 authorized auditors less than the expected count.

The questionnaire consisted of 14 questions formulated in the Swedish language to minimize misinterpretations from the respondents and to increase the reliability of the empirical study. In order to design the questionnaire, as well as increase reliability and ensure that the different variables in the questionnaire were in conformity with the study's purpose of investigation, 
three pilot tests were conducted. The pilot tests were completed by two human resource managers from two of the Big 4 audit firms, and one authorized public auditor. To test the questionnaire in practice, three pilot tests were also administered to three approved public auditors.

\subsection{Operationalization}

\subsubsection{The dependent variable(s)}

Audit quality (AQ) is measured by three indicators: (i) premature sign-off (PMS), (ii) accepting weak client explanations (AWCE) and (iii) underreporting of time (URT). These indicators have been used by several studies in order to operationalize AQ (Paino et al., 2010; Gundry \& Liyanarachchi, 2007; Malone \& Roberts, 1996; Otley \& Pierce, 1995, 1996a; Margheim \& Pany, 1986). The indicators are measured by one question for each indicator: (i) 'Do you feel unsure whether the audit is correct after you have signed off the audit?' (ii) 'Do you feel that you accept explanations from the clients that you experience as unclear?' (iii) 'Does it happen that you do not register all hours you have spent working on the client?'. For each question, we asked the respondents to rate their response on a 7-point Likert scale where $1=$ always and $7=$ never. The three AQ indicators as well as the average value of the three indicators $(A Q)$ are used as dependent variables.

\subsubsection{The independent variables}

Time budget pressure (TBP) is measured by two indicators; (i) time budget pressure is felt $(T B P F)$ and (ii) budgets are unattainable $(B U)$. These indicators are in line with measures used in other studies (Bowrin \& King, 2010; Gundry \& Liyanarachchi, 2007; Coram et al., 2003; Malone \& Roberts, 1996; Kelley \& Margheim, 1990). Thus, the questions for the two indicators are: (i) 'Do you feel time budget pressure from the budget you are working on?' (ii) 'Do you feel that the time budgets are unattainable?' For each question, we asked the respondents to rate their response on a 7-point Likert scale where $1=$ never and 7 = always.

\subsubsection{Control variables}

Johansson et al. (2005) claim that audit firms are managed and run by individuals and the audit profession is a world of people with personal strengths and weaknesses. This means that auditors' reactions to time pressures may depend on their individual characteristics (Gundry \& Liyanarachchi, 2007; Kelley \& Margheim, 1990). Pentland (1993) claims that 'comfort' is an 
important product throughout audit work and Broberg (2013) suggests that such comfort is not only a collective product but also an individual feeling that auditors associate with AQ. That is, if the individual auditor is comfortable with the audit, he or she is confident that a quality audit has been performed. This means that, besides TBP, individual characteristics, such as gender (Ittonen et al., 2013; Ittonen \& Peni, 2012; Giacomino \& Eaton, 2003), position (Gundry \& Liyanarachchi, 2007; Liyanarachchi \& McNamara, 2007) and experience (Cianci \& Bierstaker, 2009; Coram et al., 2004) can have an impact on AQ. Therefore the following control variables have been used:

- Gender (GEN): Ittonen et al. (2013) suggest that behavioural differences between females and males may influence the quality of auditing. Specifically, females are considered to be more risk averse than males. According to Ittonen and Peni (2012), female auditors spend more time than males on planning, preparing and evaluating risk. Thus, it is reasonable to assume that gender is a factor that can affect AQ. Therefore, we control for gender. GEN is measured by a dummy variable, where $0=$ Male and $1=$ Female.

- Position (POS): Several studies have shown that auditors' responses to time budgets are related to the auditors' positions in audit firms (Gundry \& Liyanarachchi, 2007; Liyanarachchi \& McNamara, 2007). According to Ettredge et al. (2008), it is very important for auditors' careers to achieve time budgets, and this is even more important for low-ranked auditors than high-ranked auditors (Gundry \& Liyanarachchi, 2007; Liyanarachchi \& McNamara, 2007; Ettredge et al., 2008). In order to control for position and auditor rank, we use formal competence as a proxy. In Sweden there are two categories of auditors: Approved public auditors (who require a three-year academic degree and three years of professional training) and authorized public auditors (who require a four-year academic degree and five years of professional training). Hence, in the analyses a dummy variable is used where $0=$ Approved public auditor and $1=$ Authorized public auditor.

- Experience (EXP): According to Cianci and Bierstaker (2009), experienced auditors are more stress-resistant than less experienced auditors. Furthermore, they are not as afraid of losing a client as less experienced auditors might be (Coram et al., 2004; Umar \& Anandarajan, 2004). On the other hand, one can imagine that the experience will lead to a sense of security which may decrease prudence. Thus, experience impacts on a person's 
behaviour and we therefore control for this factor. EXP is measured as the natural logarithm of numbers of years the auditor has worked as an auditor.

Moreover, the TBP and AQ literature has also identified factors related to the auditor situation and to where the audit takes place as decisive. Therefore the following control variables have also been used:

- Number of clients (NOC): Several studies have shown that auditors' number of clients affect the AQ (DeAngelo, 1981; Coram et al., 2003; Francis \& Wilson, 1988). There are arguments for both increased and decreased AQ due to number of clients. On the one hand, working with a large number of clients might create incentives to 'cheat' in order to retain clients in future periods and thus lead to reduced AQ. On the other hand, auditors having a large customer base have more to lose if they do not report significant errors; these incentives to behave professionally increase AQ (see also Francis \& Wilson, 1988; DeAngelo, 1981). In this study we control for number of clients (NOC), measured as the natural logarithm of the number of clients that the auditor states he/she is responsible for.

- Local office size (LOS): Francis and Yu (2009) found differences in AQ, between Big-N firms, depending on office size and available resources. We consider this by controlling for local office size (LOS) measured as the natural logarithm of number of employees working at the local office (see also Svanström \& Sundgren, 2012).

- Ask for more time (ASK): According to both Liyanarachchi and McNamara (2007) and Ettredge et al. (2008), this is an important factor to consider when analysing TBP. This was considered by a straightforward question: 'Do you often ask for more time when you feel time budget pressure?' We asked the respondents to rate their response on a 7-point Likert scale where $1=$ never and 7 = always.

- Audit firm: several studies have discussed how AQ is related to audit firm size and more specifically that higher quality audits are provided by the big audit firms (e.g. Krishnan \& Schauer, 2000; Francis \& Krishnan, 1999; Mutchler et al., 1997; Moizer, 1997; Deis \& Giroux, 1992; Palmrose, 1988; DeAngelo, 1981). In this study we control for audit firm size by using three dummy variables. Big 4 where Ernst and Young, Deloitte, KPMG, PwC equal 1, 0 otherwise; Second tier where BDO, Grant Thornton, and Mazars equal 1, 0 
otherwise. All other audit firms were included into one single category (equals 1 and 0 otherwise) and used as a reference variable.

\section{Analyses and Findings}

Table 1 shows descriptive statistics regarding the variables used in the analyses.

\section{Enter Table 1 here}

Audit Quality scores relatively high with 5.29 as mean value. This is mainly explained by the high averages for the two indicators PMS and AWCE. However, the indicator URT has the highest standard deviation. For the two indicators of time budget pressure, TBPF and BU, the average score is lower, but the standard deviation higher compared to all the AQ indicators except URT. Approximately two-thirds of the auditors are male and one-third female. The division between approved and authorized public auditors is almost equal. The sample appears to contain a distribution of respondents in terms of experience, number of clients and local office size. It seems to be quite common to ask for more time, although the standard deviation indicates a large variation. Half of the respondents work at Big 4 audit firms, almost 14\% at second tier audit firms while slightly more than a third of the respondents are working at other audit firms.

\section{Enter Table 2 here}

The correlation matrix indicates support for the hypothesis that there is a negative relationship between the indicators of AQ and the indicators of TBP. The correlation matrix also indicates positive relationship between $\mathrm{AQ}$ and auditor position and the variable ASK. A negative relationship is indicated between AQ and number of clients. Audit firms in the second tier differ positively regarding AQ compared to the category of other audit firms. Inspecting the three indicators for AQ separately, results show that PMS is negatively correlated to position and number of clients, while AWCE is positively correlated to position, experience and local office size and that URT is negatively correlated to experience and number of clients. PMS and URT are both positively correlated to the variable ASK. Big 4 audit firms differ positively from other firms in relation to AWCE and negatively when it comes to URT. Second tier firms differ positively from other firms only regarding AWCE. 
Furthermore, the correlation matrix indicates relationship between the independent variables and the control variables, e.g. the variables gender, position, experience and audit firm, are all correlated with TBPF, while the variables gender, number of clients, local office size and audit firm are correlated with BU. However, collinearity statistics show that all VIF values are far below the critical value 2.5 (Djurfelt et al., 2007).

\section{Enter Table 3 here}

The regression results are shown in Table 3. Four regression models are presented; one where the average value of the three indicators of audit quality are used as the dependent variable AQ, and three models where each indicator separately (PMS, AWCE and URT) is used as the dependent variable. In line with the hypothesis, both indicators of time budget pressure (TBP) are significant and negatively correlated with the dependent variables intended to reflect audit quality (AQ). For the full model, where the three indicators of audit quality are merged, the control variables gender (GEN), position (POS) and ask for more time (ASK) are significant and positively correlated with the dependent variable. This indicates that female auditors produce higher AQ than male auditors, that authorized public auditors produce higher AQ than approved public auditors and that auditors that often ask about more time when feeling TBP are producing higher AQ than those who rarely or never ask for more time. Number of clients (NOC) is significant and negatively correlated with the dependent variable, i.e. the more clients an auditor has, the lower audit quality. Neither experience (EXP) nor local office size (LOS) are significant in this model. The variable second tier shows a significant and positive sign, indicating that this category produces a higher AQ compared to the audit firms categorized as 'other audit firms'.

In the second model, which only uses the indicator premature sign-off (PMS) as dependent variable, the relationships are the same as in the full model, except that the variable position (POS) is not significantly correlated whereas local office size (LOS) is significant and negatively correlated with the dependent variable. Also, in this model both the variables Big 4 and second tier show significant and positive signs, indicating that auditors from these categories of audit firms to a lesser extent feel unsure if the audit is correct after they have signed off the audit compared to auditors from the audit firms categorized as 'other audit firms'.

In the third model, which only uses the indicator accepting weak client explanations (AWCE) as dependent variable, the basic correlations are the same as in the full model. The difference 
is that the variables number of clients (NOC) and ask for more time (ASK) are not significant. Also in this model both the variable Big 4 and second tier show significant and positive signs, indicating that the acceptance of weak client explanations does not occur to the same extent in these categories of audit firms as in audit firms categorized as 'other audit firms'.

The final model, which only uses the indicator underreporting of time (URT) as dependent variable, neither the variable gender (GEN), nor any of the audit firm variables are significant. However, in contrast to the other models, the variable experience (EXP) is significant and negatively correlated with the dependent variable. This means that neither gender (GEN) nor audit firm affect the propensity of underreporting of time, however, the tendency to underreport time decreases with experience. Just as in the full model (AQ) and third model (AWCE), position (POS) is significant and positively correlated with the dependent variable, i.e. authorized public auditors underreport time to a lesser extent than approved public auditors.

No matter which model or indicator of AQ used in the analyses, the result appears to be robust. Based on our data, the hypothesis 'Time budget pressure is negatively correlated with audit quality’ cannot be rejected.

\section{Discussion of the findings}

In line with the hypothesis developed in Section 2, the results of this study show a negative relationship between audit quality and time budget pressure. Thus, our findings support previous studies (Ettredge et al., 2008; McNair, 1991; Gundry \& Liyanarachchi, 2007; Otley \& Pierce, 1996a) arguing that TBP is the largest cause of reduced AQ.

However, this study of the Swedish context highlights that TBP is not the only factor that affects AQ. As far as Swedish auditors are concerned, our findings are also in line with the previous studies which declare that also gender (Ittonen et al., 2013; Ittonen \& Peni, 2012; Giacomino \& Eaton, 2003), position (Gundry \& Liyanarachchi, 2007; Liyanarachchi \& McNamara, 2007), experience (Cianci \& Bierstaker, 2009; Coram et al., 2004), number of clients (DeAngelo, 1981; Coram et al., 2003; Francis \& Wilson, 1988), local office size (Francis \& Yu, 2009), auditors asking for more time (Liyanarachchi \& McNamara, 2007; Ettredge et al., 2008) and audit firm (Krishnan \& Schauer, 2000; Francis \& Krishnan, 1999; Mutchler et al., 1997; Moizer, 1997; Deis \& Giroux, 1992; Palmrose, 1988; DeAngelo, 1981) can affect AQ. 
It has been found that there are several general differences between males and females, such as organizational, individual and personal goals (Giacomino \& Eaton, 2003). In addition, Ittonen et al. (2013) say that there are behavioural differences between males and females in the audit industry. The results from this study provide indications that in terms of premature sign-off and accepting weak client explanations, female auditors are less involved with AQ-reducing behaviour than male auditors. The reason may be, as Ittonen and Peni (2012) claim, that females use more time on planning, preparing, risk evaluation, and have higher morals than males. When it comes to underreporting of time, there are no differences between female and male auditors. This could be explained by auditors and audit firms putting great emphasis on time reporting, which could be described more as a mechanical routine within the audit firm system rather than a decision involving professional judgment (cf. Broberg, 2013). Furthermore, there are indications from the results that female auditors have fewer clients and regularly ask for more time compared to male auditors. However, what is remarkable is that there is an indication that females produce higher AQ, and at the same time experience a higher TBP than males.

Gundry and Liyanarachchi (2007) and Liyanarachchi and McNamara (2007) show that position matters in that a lower position is negatively correlated with AQ and that auditors with higher rank think that time budgets are not important to achieve, compared to the opinions of auditors in lower positions. In line with such findings, this study indicates that authorized public auditors are less involved in AQ-reducing behaviour than approved public auditors when it comes to accepting weak client explanations as well as underreporting of time. The results also indicate that authorized auditors experience a lower TBP from the budget they are working on than approved public auditors. An explanation could be that higher-ranked auditors have more education and training as well as being perceived 'superior' by clients. Therefore they might also feel more secure and have greater ability to question and put pressure on both clients and colleagues. Higher-ranked auditors more often have other roles and responsibilities within audit firms and are not involved in the audit work in the same way as lower-ranked auditors.

Experience being negatively correlated with the extent auditors experience TBP but only to AQ-reducing behaviour in terms of underreporting of time might support the explanation that the most experienced auditors are not involved in work such as gathering and examining audit evidence. They often have other roles and tasks within audit firms. Auditors with limited experience on the other hand often have tasks that are to be carried out in a certain way within a certain amount of time. As suggested by Cianci and Bierstaker (2009), Umar and Anandarajan (2004), and Colbert and Murray (1998), however, another possible explanation is that more 
experienced auditors are more stress-hardy to time budgets than less experienced auditors. Again, neither less nor more experienced auditors experience TBP to the extent that budgets are felt as unattainable.

Furthermore, neither authorized nor approved auditors, and neither less nor more experienced auditors experience time budgets as unattainable (the mean value is low and there are no differences due to position or experience), and there are no difference between them when it comes to AQ-reducing behaviour in terms of premature sign-offs. Thus, irrespective of position and experience, auditors experience TBP but not to the extent that budgets are felt as unattainable. Regardless of position and experience, the same firm-specific routines and systems (e.g. checklists, manuals, etc.) are used throughout the audit work and dictate when an audit is considered sufficient (cf. Broberg, 2013).

This study found indications that number of clients is negatively correlated with AQ-reducing behaviour in terms of premature sign-off and underreporting of time. This finding contradicts those of Coram et al. (2003), Francis and Wilson (1988) and DeAngelo (1981), pointing out that high number of clients is less associated with AQ-reducing behaviour. An explanation of the negative relationship between number of clients and AQ-reducing behaviour could be that auditors with few clients have less experience (this is supported by the correlation between experience and number of clients) and more regularly ask for more time, which means less frequent occurrence of AQ-reducing behaviour. Thus, they do not need to sign off audits prematurely or underreport time. This explanation is supported by the correlations found in this study. Asking for more time is positively related to AQ, and auditors with more experience are less inclined to ask for more time. However, when it comes to accepting weak client explanations, there is no correlation with number of clients nor with auditors asking for more time, suggesting that the acceptance of weak client explanations might not only be connected to TBP but also due to other type of pressures deriving from the relationship with the client.

The study showed significant differences in AQ-reducing behaviour between different categories of audit firms. When it comes to premature sign-offs and accepting weak client explanations, both Big 4 and second tier audit firms seem to produce higher AQ than audit firms in the 'other audit firms' category. Underreporting of time is the only AQ indicator that is not related to audit firm, meaning that such behaviour is widespread and not related to the audit firm that employs the individual auditor. 


\section{Conclusions}

The aim of this paper is to explain how TBP influences AQ in the Swedish context. The empirical analysis indicates that auditors experiencing higher TBP are more inclined to engage in AQ-reducing behaviour such as premature sign-offs, accepting weak client explanations and underreporting of time.

Throughout this paper we have shown how both AQ and TBP are affected by a number of factors. Our argument was that institutional pressures that are felt in the audit industry have major influence on audit firms and affect the individual auditors and their performance. A thorough understanding of this relationship needs to take into account who the auditors are as individuals as well as the specific local context in which they operate. In this paper we have focused on some individual and local context aspects and thereby paved the way for further studies including additional aspects.

The practical implications of this study are also evident in that when trading-off between audit efforts and available resources and setting time budgets for each audit assignment, audit firms should also consider the personal characteristics of the auditors as well as their local context.

Given that there are institutional pressures influencing AQ via auditor behaviour one can argue that the increasing competition and public scrutiny may also influence auditors' well-being in terms of job satisfaction, life satisfaction and life balance. This study has shown that auditors experience TBP, but at the same time research has indicated that auditors have a high level of well-being (Umans et al., 2016). This seems to be a paradox and we suggest that future research could study the relationship between TBP and auditor well-being. 


\section{References:}

Alderman, C.W. \& Deitrick, J.W. (1982). Auditors’ perceptions of time budget pressures and premature sign-offs: a replication and extension. Auditing: A Journal of Practice \& Theory, 1 (2), 54-68.

Alvesson, M. (1994). Talking in organizations: managing identity and impressions in an advertising agency. Organization Studies, 15 (4), 535-563.

Anderson-Gough, F., Grey, C. \& Robson, K. (2000). In the name of the client: the service in two professional services firms. Human Relations, 53 (9), 1151-1173.

Anderson-Gough, F., Grey, C. \& Robson, K. (2001). Test of time: organizational timereckoning and the making of accountants in two multi-national accounting firms. Accounting, Organizations and Society, 26 (2), 99-122.

Anderson-Gough, F., Grey, C. \& Robson, K. (2002). Accounting professionals and the accounting profession: linking conduct and context. Accounting and Business Research, 32 (1), 41-56.

Blake, J., Amat, O., Gowthorpe, C. \& Pilkington, C. (1998). International accounting harmonisation - a comparison of Spain, Sweden and Austria. European Business Review, 98 (3), 144-150.

Bowrin, R. A. \& King, J. (2010). Time pressure, task complexity, and audit effectiveness. Managerial Auditing Journal, 25 (2), 160-181.

Brante, T. (1988). Sociological approaches to the professions. Acta Sociologica, 31 (2), 119142.

Broberg, P. (2013). The auditor at work - A study of auditor practice in Big 4 audit firms. Diss. Lund University, Lund.

Broberg, P., Umans, T. \& Gerlofstig, C. (2013). Balance between auditing and marketing: an explorative study. Journal of International Accounting, Auditing and Taxation, 22 (1), 57-70.

Broberg, P., Umans, T. Skog, P. \& Theodorsson, E. (2014). Auditors' professional and organizational identities and perceived commercialization in auditing firm. Presented at the 37th Annual Meeting of European Accounting Association, Tallinn, Estonia. May 2014.

Cianci, A.M. \& Bierstaker, J. (2009). Auditors' efficiency motivated evaluation. Advances in Accounting: Incorporating Advances in International Accountning, 25 (1), $20-27$.

Clow. K.E., Stevens, R.E., McConkey, C.W. \& Loudon, D.L. (2009). Accountants' attitudes towards advertising: a longitudinal study. Journal of Services Marketing, 23 (2), 125132.

Colbert, G. \& Murray, D. (1998). The association between auditor quality and auditor size: an analysis of small CPA firms. Journal of Accounting, Auditing \& Finance, 13 (2), 135150.

Colbert, G. \& Murray, D. (1999). State accountancy regulations: audit firm size, and auditor quality: an empirical investigation. Journal of Regulatory Economics, 16 (3), 267-285.

Cooper, D. J. \& Robson, K. (2006). Accounting, professions and regulation: locating the sites of professionalization. Accounting, Organizations and Society, 31 (4/5), 415-444.

Coram, P., Ng, J. \& Woodliff, D. R., 2003. A survey of time budget pressure and reduced audit quality among Australian auditors. Australian Accounting Review, 13 (29), 38-44.

Coram, P., Ng, J. \& Woodliff, D. R. (2004). The effect of risk of misstatement on the propensity to commit reduced audit quality acts under time budget pressure. Auditing: A Journal of Practice \& Theory, 23 (2), 159-167.

Coram, P., Glavovic, A., Ng, J. \& Woodliff, D. R. (2008). The moral intensity of reduced audit quality acts. Auditing: A Journal of Practice \& Theory, 27 (1), 127-149. 
Covaleski, M. A., Dirsmith, M, W., Heian, J. B. \& Samuel, S. (1998). The calculated and the avowed: techniques of discipline and struggles over identity in big six public accounting firms, Administrative Science Quarterly, 43 (2), 293-327.

DeAngelo, L. (1981). Auditor size and audit quality. Journal of Accounting and Economics, 3 (3), 183-199.

Deis, D. R. \& Giroux, G. A. (1992). Determinants of audit quality in the public sector. The Accounting Review, 67 (3), 462-479.

Dillard, J. F. \& Bricker, R. (1992). A critique of knowledge-based systems in auditing: the systemic encroachments of technical consciousness. Critical Perspectives in Accounting, 3 (3), 205-224.

Dirsmith, M.W. \& Covaleski, M.A. (1985). Informal communications, nonformal communications, and mentoring in public accounting. Accounting, Organizations and Society, 10 (2), 149-169.

Dirsmith, M. W., Heian, J. B. \& Covaleski, M. A. (1997). Structure and agency in an institutionalized setting: The application and social transformation of control in the big six. Accounting, Organizations and Society, 22 (1), 1-17.

Djurfeldt, G., Larsson, R. \& Stjärnhagen, O. (2007). Statistisk verktygslåda samhällsvetenskaplig orsaksanalys med kvantitativa metoder. Studentlitteratur, Lund.

EC. (2010). Green Paper. Audit Policy: Lessons from the Crisis, European Commission, Brussels, October.

Ellingson, D. A., Hiltner, A. A., Elbert, D. J. \& Gillett, J. (2002). Marketing: where do accountants stand today? Services Marketing Quarterly, 23 (3), 1-15.

Ettredge, L. M., Bedard, C. J. \& Johnstone, M. K. (2008). Empirical tests of audit budget dynamics. Behavioral Research in Accounting, 20 (2) 1-18.

Fischer, M. J. (1996). Realizing the benefits of new technologies as a source of audit evidence: an interpretive field study. Accounting, Organizations and Society, 21 (2/3), 210-242.

Fogarty, T. J. (1992). Organizational socialization in accounting firms: a theoretical framework and agenda for future research. Accounting, Organizations and Society, 17 (2), 129-149.

Francis, J. R. (2004). What do we know about audit quality? British Accounting Review, 36 (4), 345-368.

Francis, J. R. \& Krishnan, J. (1999). Accounting accruals and auditor reporting conservatism. Contemporary Accounting Research, 16 (1), 135-165.

Francis, J. R. \& Simon, D. T. (1987). A test of audit pricing in the small-client segment of the US audit market. The Accounting Review, 62 (1), 145-157.

Francis, J. R. \& Wilson, E. R. (1988). Auditor changes: a joint test of theories relating to agency costs and auditor differentiation. The Accounting Review, 63 (4), 663-682.

Francis, J. R. \& Yu, M. D. (2009). Big 4 office size and audit quality. The Accounting Review, 84 (5), 1521-1552.

Francis, J.R. (2011). A framework for understanding and researching audit quality. Auditing: A Journal of Practice \& Theory: Vol. 30, No. 2, pp. 125-152

Gaertner, J. F. \& Ruhe, J. A. (1981). Job-related stress in public accounting. Journal of Accountancy, 151 (6), 68-74.

Giacomino, D. E. \& Eaton, T. V. (2003). Personal values of accounting alumni: an empirical examination of differences by gender and age. Journal of Managerial Issues, 15 (3), 369380.

Grey, C. (1998). On being a professional in a "big six" firm". Accounting, Organizations and Society, 23 (5/6), 569-587.

Gundry, C. L. \& Liyanarachchi, A. G. (2007). Time budget pressure, auditors' personality type, and the incidence of reduced audit quality practices. Pacific Accounting Review, 19 (2), 125-152. 
Gyllengahm, N., \& Mårtensson, O. (2012). The extent of reduced audit quality - Do time budget pressure and individual factors lead to reduced audit quality in the Swedish context? [Master Thesis] Kristianstad University.

Hanlon, G. (1996). Casino capitalism and the rise of the commercialised service class - An examination of the accountant. Critical Perspectives on Accounting, 7 (3), 339-363.

Heischmidt, K., Elfrink, J. \& Mays, B. (2002). Professional accounting services: Types of marketing communications used by CPAs. Services Marketing Quarterly, 23 (3), 63-72.

Herrbach, O. (2001). Audit quality, auditor behaviour and the psychological contract. European Accounting Review, 10 (4), 787-802.

Houston, R. W. (1999). The effect of fee pressure and client risk on audit seniors' time budget decisions. Auditing: A Journal of Practice \& Theory, 18 (2), 70-86.

Hyatt, T. A. \& Taylor, M. H. (2013). The effects of time budget pressure and intentionality on audit supervisors' response to audit staff false sign-off. International Journal of Auditing, 17 (1), 38-53.

IAASB, (2010). IAASB Response to EC Green Paper, available at: $<$ http://www.ifac.org/sites/default/files/meetings/files/6090_0.pdf $>\quad$ (accessed 22 October 2014).

ICAEW, (2002). Audit Quality. Institute of Chartered Accountants in England \& Wales, Audit and Assurance Faculty, Audit Quality, November, 2002.

IFAC, (2011). Integrating the business reporting supply chain. A report based on recommendations from key business leaders from around the world. International Federation of Accountants, March 2011, available at: http://viewer.zmags.com/publication/5d630be3\#/5d630be3/1 (accessed 22 October 2014).

ISA 200. International Standard on Auditing 200, Overall objectives of the independent auditor and the conduct of an audit in accordance with international standards on auditing. (Effective for audits of financial statements for periods beginning on or after December 15, 2009).

Ittonen, K. \& Peni, E. (2012). Auditor's gender and audit fees. International Journal of Auditing, 16 (2), 1-18.

Ittonen, K., Vähämaa, E. \& Vähämaa, S. (2013). Female auditors and accruals quality. Accounting Horizons, 27 (2), 205-228.

Johansson, S. E., Häckner, E. \& Wallerstedt, E. (2005). Uppdrag revision Revisorsprofessionen i takt med förväntningarna, SNS Förlag, Stockholm.

Kelley, T. \& Margheim, L. (1990). The impact of time budget pressure, personality, and leadership variables on dysfunctional auditor behavior. Auditing: A Journal of Practice \& Theory, 9 (2), 21-42.

Kinney, W. R., Palmrose, Z. V. \& Scholtz, S. (2004). Auditor independence, non-audit services and restatements: Was the US Government right? Journal of Accounting Research, 42 (3), 561-588.

Knechel, W.R., Krishnan, G.V,, Pevzner, M. Shefchik, L. B \& Velury, U.K (2013). Audit Quality: Insights from the academic literature. Auditing: A Journal of Practice \& Theory, 32(2), 385-421.

Kosmala, K. (2005). Insights from Ricoeur's hermeneutics in best practice in professional service firms: on perpetual myth creation? Qualitative Sociology Review, 1 (1), 31-50.

Krishnan, J. \& Schauer, P. C. (2000). The differentiation of quality among auditors: evidence from the not-for-profit sector. Auditing: A Journal of Practice \& Theory, 19 (2), 9-25.

Larker, D. F. \& Richardson, S. A. (2004). Fees paid to auditors, accruals, choices and corporate governance. Journal of Accounting Research, 42 (3), 625-658. 
Liyanarachchi, A. G. \& McNamara, M. S. (2007). Time budget pressure in New Zealand audits. University of Auckland Business Review, 9 (2), 60-68.

López, D. M., \& Peters, G. F. (2012). The effect of workload compression on audit quality. Auditing: A Journal of Practice \& Theory: 31 (4), 139-165.

Malone, C. F. \& Roberts, R. W. (1996). Factors associated with the incidence of reduced audit quality behaviours. Auditing: A Journal of Practice \& Theory, 15 (2), 315-333.

Margheim, L. \& Pany, K. (1986). Quality control, premature signoffs and underreporting of time: some empirical findings. Auditing: A Journal of Practice \& Theory, 5 (2), 50-63.

McDaniel, L. (1990). The effects of time pressure and audit program structure on audit performance. Journal of Accounting Research, 28 (2), 267-285.

McNair, C. (1991). Proper compromises: the management control dilemma in public accounting and its impact on auditor behavior. Accounting, Organizations and Society, 16 (7), 635-653.

McNair, C. (1987). The effects of budget pressure on audit firms: an empirical examination of the underreporting of chargeable time. Columbia University, New York.

Moizer, P. (1997). Auditor reputation: the international empirical evidence. International Journal of Auditing, 1 (1), 61-74.

Mutchler, J. F., Hopwood, W. \& McKeown, J. M. (1997). The influence of contrary information and mitigating factors on audit opinion decisions on bankrupt companies. Journal of Accounting Research, 35 (2), 295-310.

Öhman, P. \& Wallerstedt, E. (2012). Audit regulation and the development of the auditing profession: The case of Sweden. Accounting History, 17 (2), 241-257.

Oliver, C. (1991). Strategic responses to institutional processes. Academy of management review, 16(1), 145-179.

Otley. D. T. \& Pierce, B. J. (1995). The control problem in public accounting firms: an empirical study of the impact of leadership style. Accounting, Organizations and Society, 20 (5), 405-420.

Otley, D. T. \& Pierce, B. J. (1996a). Auditor time budget pressure: consequences and antecedents. Accounting, Auditing \& Accountability Journal, 9 (1), 31-58.

Otley, D. T. and Pierce, B. J. (1996b). The operation of control systems in large audit firms. Auditing: A Journal of Practice \& Theory, 15 (2), 65-84.

Paino, H., Ismail, Z. \& Smith, M. (2010). Dysfunctional audit behavior: an exploratory study in Malaysia. Asian Review of Accounting, 18 (2), 162-173.

Palmrose, Z. V. (1986). Audit fees and auditor size: further evidence. Journal of Accounting Research, 24 (1), 97-110.

Palmrose, Z. V. (1988). Analysis of auditor litigation and audit service quality. The Accounting Review, 63 (1), 55-73.

Pentland, B. T. (1993). Getting comfortable with numbers: auditing and the micro-production of macro-order. Accounting, Organizations and Society, 18 (7/8), 605-620.

Pierce, B. \& Sweeney, B. (2003). Auditor responses to cost controls. Irish Accounting Review, $10(1), 45-68$.

Pierce, B. \& Sweeney, B. (2004). Cost-quality conflict in audit firms: An empirical investigation. European Accounting Review, 13 (1), 415-441.

Pierce, B. \& Sweeney, B. (2006). Perceived adverse consequences of quality threatening behaviour in audit firms. International Journal of Auditing, 10 (1), 19-39.

Power, M. K. (1991). Educating accountants: Towards a critical ethnography. Accounting, Organizations and Society, 16 (4), 333-353.

Power, M. K. (2003). Auditing and the production of legitimacy. Accounting, Organizations and Society, 28 (4), 379-394. 
Raghunathan, B. (1991). Premature signing-off of audit procedures: an analysis. Accounting Horizons, 5 (2), 71-79.

SFS 1982:739 Lag om ändring i aktiebolagslagen [Act amending the Companies Act], Stockholm.

Shapeero, M., Hian, C. K. \& Killough, L. N. (2003). Underreporting and premature sign-off in public accounting. Managerial Auditing Journal, 18 (6), 478-489.

Sikka, P. (2009). Financial crisis and the silence of the auditors. Accounting, Organizations and Society, 34 (6/7), 868-873.

Svanström, T. \& Sundgren, S. (2012). The demand for non-audit services and auditor-client relationships: evidence from Swedish small and medium-sized enterprises. International Journal of Auditing, 16 (1), 54-78.

Sweeney, B. \& Pierce, B. (2006). Good hours, bad hours and auditors' defence mechanisms in audit firms. Accounting, Auditing \& Accountability Journal, 19 (6), 858-892.

Tang, T. L-P., Moser, H. R. \& Austin, M. J. (2002). Attitudes toward advertising by accountants. Services Marketing Quarterly, 23 (3), 35-62.

Umar, A. \& Anandarajan, A. (2004). Auditors' independence of judgment under pressure. Internal Auditing, 19 (1), 22-32.

Umans, T., Broberg, P., Schmidt, M., Nilsson, S. \& Olsson, E. (2016). Feeling well by being together: Study of Swedish auditors. WORK: A Journal of Prevention, Assessment, and Rehabilitation, forthcoming.

Warren, C. S. (1984). "Discussant's Response on the Case of the Unstructured Audit Approach”, in Stettler, H. F. \& Ford, N.A. (Ed.), Auditing Symposium VII: proceedings of the 1984 Touche Ross/University of Kansas Symposium on Auditing Problems, University of Kansas, Lawrence, pp. 69-71. 
Table 1: Descriptive statistics - dependent, independent and control variables $(n=746)$

\begin{tabular}{|c|c|}
\hline Variables & \\
\hline Dependent variable & \\
\hline Audit quality (AQ) Mean/S.D & $5.2900 / 1.01901$ \\
\hline Premature sign-off (PMS) Mean/S.D & $5.7051 / 1.20576$ \\
\hline Accepting weak client explanations (AWCE) Mean/S.D & $5.6193 / 1.24668$ \\
\hline Underreporting of time (URT). Mean/S.D & $4.5456 / 1.78320$ \\
\hline Independent variables & \\
\hline Time budget pressure (TBP) & \\
\hline Time budget pressure is felt (TBPF) Mean/S.D & $4.2300 / 1.52100$ \\
\hline Budgets are unattainable (BU) Mean/S.D & $3.5200 / 1.44300$ \\
\hline Control variables & \\
\hline Gender (GEN) & \\
\hline Male & $66.4 \%(495)$ \\
\hline Female & $33.6 \%(251)$ \\
\hline Position (POS) & \\
\hline Approved & $49.5 \%(369)$ \\
\hline Authorized & $50.5 \%(377)$ \\
\hline Experience (EXP) Mean/S.D & $2.7639 / .69370$ \\
\hline Number of clients (NOC) Mean/S.D & $4.1700 / 1.12400$ \\
\hline Local office size (LOS) Mean/S.D & $3.4002 / 1.63704$ \\
\hline Ask for more time (ASK) Mean/S.D & $4.3900 / 1.85900$ \\
\hline Audit firm & \\
\hline Big 4 & $50.0 \%(373)$ \\
\hline Second tier & $13.8 \%(103)$ \\
\hline Other audit firms & $35.9 \%$ (268) \\
\hline
\end{tabular}


Table 2 - Pearson correlation matrix $(n=746)$

\begin{tabular}{|c|c|c|c|c|c|c|c|c|c|c|c|c|c|}
\hline & $\mathrm{AQ}$ & PMS & AWCE & $U R T$ & TBPF & $B U$ & GEN & POS & EXP & NOC & LOS & ASK & Big 4 \\
\hline Audit quality (AQ) & 1 & & & & & & & & & & & & \\
\hline Premature sign-off (PMS) & $.701^{* * *}$ & & & & & & & & & & & & \\
\hline $\begin{array}{l}\text { Accepting weak client explanations } \\
\text { (AWCE) }\end{array}$ & $.697^{* * *}$ & $.436^{* * *}$ & & & & & & & & & & & \\
\hline Underreporting of time (URT). & $.753^{* * *}$ & $.221^{* * *}$ & $.202^{* * *}$ & & & & & & & & & & \\
\hline Time budget pressure is felt (TBPF) & $-.310^{* * *}$ & $-.142^{* * *}$ & $-.194^{* * *}$ & $-301^{* * *}$ & & & & & & & & & \\
\hline Budgets are unattainable $(B U)$ & $-.340^{* * *}$ & $-.205^{* * *}$ & $-.198^{* * *}$ & $-.305^{* * *}$ & $.546^{* * *}$ & & & & & & & & \\
\hline Gender (GEN) & .054 & $.085^{*}$ & .047 & .003 & $.139^{* * *}$ & $.094^{* *}$ & & & & & & & \\
\hline Position (POS) & $.119^{* * *}$ & $-.065^{\dagger}$ & $.186^{* * *}$ & .031 & $-.075^{*}$ & -.036 & $-.096^{* *}$ & & & & & & \\
\hline Experience (EXP) & -.002 & .008 & $.106^{* *}$ & $-.082 *$ & $-.134^{* * *}$ & -.054 & $-.183^{* * *}$ & $.433^{* * *}$ & & & & & \\
\hline Number of clients (NOC) & $-.093^{*}$ & $-.076^{*}$ & -.008 & $-.102^{* *}$ & -.055 & $-.114^{* *}$ & $-.242^{* * *}$ & $.110^{* *}$ & $.439^{* * *}$ & & & & \\
\hline Local office size (LOS) & .057 & .027 & $.114^{* *}$ & .001 & .057 & $.086^{*}$ & .039 & $.241^{* * *}$ & $-.042 *$ & $-.346^{* * *}$ & & & \\
\hline Ask for more time (ASK) & $.110^{* *}$ & $.105^{* *}$ & .050 & $.083^{*}$ & -.007 & -.016 & $.062^{\dagger}$ & .019 & $-.152^{* * *}$ & $-.105^{* *}$ & $.215^{* * *}$ & & \\
\hline \multicolumn{14}{|l|}{ Audit firm } \\
\hline Big 4 & .007 & .047 & $.090^{*}$ & $-.083^{*}$ & $.183^{* * *}$ & $.194^{* * *}$ & -.003 & $.196^{* * *}$ & -.039 & $-.330 * * *$ & $.524^{* * *}$ & $.141^{* * *}$ & \\
\hline Second tier & $.070^{\dagger}$ & .043 & $.072^{*}$ & .041 & -.053 & $-.082 *$ & -.005 & .031 & .026 & $.121^{* * *}$ & $.074^{*}$ & .018 & $.400^{* * *}$ \\
\hline
\end{tabular}


Table 3: Regression model $(n=746)$

Regression model: (Dependent variable $=\alpha+b_{1} \mathrm{TBPF}_{1}+b_{2} \mathrm{BU}_{2}+b_{3} \mathrm{GEN}_{3}+b_{4} \mathrm{POS}_{4}+b_{5} \mathrm{EXP}_{5}+b_{6} \mathrm{NOC}_{6}+b_{7} \mathrm{LOS}_{7}+b_{8} \mathrm{ASK}_{8}+b_{9 a} \mathrm{Big}_{99_{a}}+b_{9 b} \mathrm{Second}_{\mathrm{Tier}}{ }_{9 b}+\varepsilon$ )

\begin{tabular}{|c|c|c|c|c|c|c|c|c|c|c|}
\hline \multicolumn{2}{|l|}{ Variables/Dependent variable } & $\mathrm{AQ}$ & & PMS & & AWCE & & URT & & \\
\hline & $\begin{array}{l}\text { Predicted } \\
\text { relationship }\end{array}$ & $\mathrm{B}$ & SE (b) & $\mathrm{B}$ & SE (b) & $\mathrm{B}$ & SE (b) & $\mathrm{B}$ & SE (b) & VIF \\
\hline Constant & & $6.541^{* * *}$ & .251 & $6.322 * * *$ & .316 & $5.708 * * *$ & .321 & $7.594^{* * *}$ & .449 & \\
\hline \multicolumn{11}{|l|}{ Time budget pressure (TBP) } \\
\hline $\begin{array}{l}\text { Time budget pressure is felt } \\
(T B P F)\end{array}$ & - & $-.125 * * *$ & 0.27 & -.044 & .034 & $-.109 * *$ & .035 & $-.222 * * *$ & .049 & 1.504 \\
\hline Budgets are unattainable $(B U)$ & - & $-.182 * * *$ & .028 & $-.166 * * *$ & .036 & $-.130 * * *$ & .036 & $-.250 * * *$ & .051 & 1.461 \\
\hline Gender (GEN) & + & $.180^{*}$ & .075 & $.255^{* *}$ & .094 & $.263 * *$ & .096 & .023 & .134 & 1.102 \\
\hline Position (POS) & + & $.232 * *$ & .079 & .116 & .100 & $.301 * *$ & .101 & $.279 *$ & .142 & 1.371 \\
\hline Experience (EXP) & $-/+$ & -.023 & .062 & .069 & .077 & .096 & .079 & $-.233 *$ & .110 & 1.1589 \\
\hline Number of clients (NOC) & $-/+$ & $-.099 * *$ & .038 & $-.098 *$ & .048 & -.002 & .048 & $-.197 * *$ & .068 & 1.581 \\
\hline Local office size (LOS) & + & -.026 & .028 & $-.068 *$ & .035 & .004 & .035 & -.015 & .049 & 1.770 \\
\hline Ask for more time (ASK) & + & $.044 *$ & .019 & $.059 *$ & .024 & .014 & .024 & $.060^{\dagger}$ & .034 & 1.082 \\
\hline \multicolumn{11}{|l|}{ Audit firm } \\
\hline Big 4 & + & .154 & .097 & $.312 *$ & .122 & $.402 * * *$ & .124 & -.252 & .173 & 2.051 \\
\hline Second tier & + & $.242 *$ & .116 & $.314^{*}$ & .145 & $.406 * *$ & .148 & .005 & .207 & 1.389 \\
\hline \multicolumn{2}{|l|}{ R2/Adj. R2/F Value/Sig. } & \multicolumn{2}{|c|}{$.187 / .176 / 14.442 / .000$} & \multicolumn{2}{|c|}{$.085 / .072 / 6.790 / .000$} & \multicolumn{2}{|c|}{$.113 / .101 / 9.345 / .000$} & \multicolumn{2}{|c|}{$.152 / .141 / 13.217 / .000$} & \\
\hline
\end{tabular}

† Correlation is significant at the 0.10 level (2-tailed)

* Correlation is significant at the 0.05 level (2-tailed).

** Correlation is significant at the 0.01 level (2-tailed).

*** Correlation is significant at the 0.001 level (2-tailed). 